\title{
Why we can not teach a foreign language? The cognitive learning approach on language acquisition according to the views of the language teachers
}

\section{Cem Özkurt*, Serhat Arslan **}

* Sakarya University

E-mail: ozkurtcemm@gmail.com

Copyright (C) 2015 Cem Özkurt, Serhat Arslan. This is an open access article distributed under the Eurasian Academy of Sciences License, which permits unrestricted use, distribution, and reproduction in any medium, provided the original work is properly cited.

\begin{abstract}
The purpose of this study mainly aims on making a detailed research on the issues and the methods used by the language teachers about teaching a foreign language. In the current study qualitative research method and semi-structural interview method were used. With semistructural interview form teachers' opinions about the cognitive learning approach on language acquisition was determined. In the present study purposeful sampling was used with 17 language teachers were interviewed in Sakarya. With using the descriptive method, a content analyse was accomplished with the obtained data. According to the findings the teaching and the learning methods of a foreign language need to be changed comprehensively
\end{abstract}

Keywords: Language acquisition, teaching methods, learning methods

\section{Yabancı dili niçin öğretemiyoruz? Yabancı dil öğreniminde zihinsel edinim temelli öğrenim yaklaşımının yabancı dil öğretmenlerinin görüşlerine göre incelenmesi}

\section{ÖZET}

Bu çalışmanın amacı yabancı dil öğretmenlerinin, yabancı dil öğretimi süreci içerisindeki çeşitli konu ve yöntemlerle ilgili görüşlerinin incelenmesidir. Araştırmada nitel araştırma yöntemlerinden görüşme tekniği kullanılmıştır. Araştırmacılar tarafından yarı yapılandırılmış görüşme formu hazırlanmış ve 17 yabancı dil öğretmeninin dil edinimine yönelik görüşleri alınmıştır. Çalışmada amaçlı örnekleme yöntemi kullanılmıştır. Toplanan nitel verilerin betimsel method yardımıyla içerik analizi yapılmıştır. Araştırmanın sonuçlarına göre, öğretim yöntemlerinde kapsamlı bir bakış açısı değişikliğinin gerekmektedir.

Anahtar Kelimeler: Dil edinimi, öğretim yöntemleri, öğrenme yöntemleri

\section{Introduction}

The utmost necessity for a student in acquisition of a language is the natural communication. At this point, especially it is not important that what was written on the paper, the important part is the communication itself. For the teachers, instead of using the more communicative parts of the language, using the grammatical rules or focusing mainly on memorizing, the 
acquisition of a language in a student's brain is developed within the first stages of his or her life or in the acquisitional learning phase. In researches, it can be seen that among the young students which can acquisite a second language can have a better job experience than the others ( Kabaday1, 2003 ).A different aspect of the skilled students, the teaching methods which are used in the language learning centers or in the language courses are unfortunately not in relation with the methodology of teaching and also ignoring it. Almost in all the trainings, the detailed grammatical rules, phrases and the useless memerozing methods are taught to the students and it can be easily said that the student isn't treated like a human being. These like courses can only promise their students accomplishing the training, netiher that the student can speak meaningfully $i$ that language nor he or she can have the advanced skills ( Akpınar ve Aydin, 2009 ). During the period of a study without speaking with a student, communication can not be established. Again when we have a look from a different aspect, the studies made in a class are mostly based on the grammatical rules ; the tenses, the rules, the multiple choice exams ... ( Ekmekçi, 1983 ).How all of these are related with the acquisition period of a language of a child ? The main reason for not understanding a second language for most of the people is originated from this point. This period is called as the language learning phase and again unfortunately today almost all the studies deprived of this period. With directly teaching these grammatical rules to young or skilled students causes this process.Even well doing the multiple choice test or fill in the blanks like questions, a student never can speak fluentlty nor he can describe himself ( Aydin, 2001 ).As a learning method, a student can memorize almost all of the grammer rules and seems to have success in an ezamination, in contrast with that when he or she confronts somebody who wants to talk with him, he or she can not produce 2 basic statements about the situation. Maybe using the memorizing method at least, using the daily phrases mostly even in period of study can make the student think that he or she has a role in a community and can descirbe herself to the induviduals and make an easier communication between them and also this can lead him to recall all of the occurances about the situations that had happened before.( Chomsky, 2008 ) Therefore we can say : the teacher's mani duty is to provide good ambience for acquisition and the student's is only the learning. This point, we have to consider the language learning period separated into volumes or different timelines. It can be observed that with depending on the age difference the total acquisition of a language is going to be differed. Within the adaption period, to struggle with the environment the student is going to make a better communication whilst designing new compounds or structures in his mindset. ( Johnson, 1982 ). But also, it has to be considered that using this structurel rules in daily life can cause mechanical studyings as we opposed earlier this study and if this can be kept for a long period it is giong to cause some new problems about the learning phase.

\section{Methodology}

In this research, amongst the qualitative research methods, the interview technique was used. $\mathrm{Bu}$ araştırma, nitel araştırma yöntemleri içerisinden görüşme tekniği kullanılarak yapılmıştır. The interview form is consisting of seven open-ended questions established on the commitments of some specialists. It had been asked to the foreign language teachers that their methodolgy of teaching, the applications they use, the reasons why the students couldn't learn a language, being male or female can effect language learning, which of the teaching methods are hard, the hardest part in the aspect of a student to learn a language, the affect of culture to learning, being outside of a calssroom which activities can be done. In the research, depending on the purposed example method, 17 primary, secondary, high school and university teachers have been interviewed in Sakarya Adapazarı county. This example group of teachers are consisting of 4 males and 13 females.The average age is 43,3 and seniority is 16,2 . Within 
gathering written examples they were analysed in descriptive method. The descriptive analyse is consisting of 4 periods : establishing a framework, processing the infromation in thematic view, defining the findings, and the interpretation of these findings . (Yildirım ve Şimşek, 2008:224). All the information were classified into themes by the researchers and coded separately.After this process, the common themes were established and within agreement of the study group they were coded. The teachers which had been interviewed were coded like T1, $\mathrm{T} 2, \mathrm{~T} 3 \ldots$

\section{Findings}

The teachers' comments about the language teaching applications are showed in tables below. The research of the methods used by the teachers are descripted in Table-1 :

Table 1. Teachers' opinions about the methods used by the teachers

\begin{tabular}{llll}
\hline Theme/Category & Codes & $\mathbf{n}$ & \% \\
\hline \multirow{3}{*}{ Favorite } & Dialog. (T1, T3, T4, T8,T14) & 5 & 30 \\
method & Improvisation. (T2, T3) & 2 & 10 \\
& Writing-Translation. (T3,T4,T9,T10,T11) & 5 & 30 \\
& Question-Answer. (T4,T7) & 2 & 10 \\
& Reading. (T5,T6,T7) & 3 & 17 \\
& Audio-Visual (T5,T6,T7,T8,T10,T12,T15) & 7 & 40 \\
\hline \multirow{2}{*}{$\begin{array}{l}\text { Unfavorite } \\
\text { method }\end{array}$} & Frequently repetition. (T1) & 1 & 5 \\
\hline
\end{tabular}

When we analyze Table 1, the audio-visual method used by the teachers has the $\% 40$ and the biggest of them all. And the others in order, \%30 dialogue and Writing-Translation, \%17 reading, $\% 10$ improvisation and question-answer , $\% 5$ frequent repetitions. The citations taken one-to-one from the teachers' comments are :

"The audio-visual activities are always beneficial. Everytime being in grammar makes the student bored and doesn't make them talk." (T5)

"I'm making lyrics about popular music and the translation of it makes them better in learning.“ (T7)

"A student only wants to get the higher score from the examination so they don't think anything else. In this aspect, "Grammar Translation Method" and making examples in a written mode fulfills the situation." (T11)

"Improvisation is the best. And also the group workings are." (T2)

"They like listening to the authentic language. Dialogue or speakings are also suitable for them." (T16) 
Tablo 2. Teachers' opinions about the affects that casued the students not learn a foreign language

\begin{tabular}{llll}
\hline $\begin{array}{l}\text { Theme } \\
\text { (Category) }\end{array}$ & Codes & $\mathbf{n}$ & $\%$ \\
\hline & Usual usage of native language (T6,T7,T8,T9) & & \\
& Not acting like in daily life (T1,T4,T8,T10,T11,T14,T15) & 4 & 23 \\
& Extreme self-confidence (T2) & 7 & 40 \\
Reasons for & Timid (T1) & 1 & 5 \\
not learning a a & a of experience in learning (T4,T12) & 1 & 5 \\
language & Lack of word learning (T3,T7) & 2 & 11 \\
& Not like the lecture (T5) & 2 & 11 \\
& Preference of the teaching method (T5) & 1 & 5 \\
& Careless, not needing (T16, T17) & 1 & 5 \\
& Lack of repetition (T13,T14) & 2 & 11 \\
\end{tabular}

When table 2 analysed carefully, the most efficient factor for the students not learning a foreign language is with the $\% 40$ not acting like in daily life. The other comments are, $\% 23$ using frequently the native language, $\% 11$ lack of word learning, not needing, lack of repetition can be seen. The citations taken one-to-one from the teachers' comments are :

"The students are not living the language in their lives. They think the language only as a lecture and study with it only before the examinations. As a result of this, they know the grammar very well but they can not use the language in their life as a native." (T3)

"Generally the students think in their native language and want to act in foreign one. This is the main reason that they can not build ud the language.Besides, in their studies, they don't learn enough words as they can use them." (T7)

"The students only think that they can learn the language in their lectures and they are avoiding making practices." (T10)

"The most efficient factor is they want to learn the foreign language as the same to the native one.” (T9)

Tablo 3. Teachers' opinions about the affect of the gender on learning a foreign language

\begin{tabular}{llll}
\hline Theme/Category & Codes & $\mathbf{n}$ & $\%$ \\
\hline & Depends on personality $(\mathrm{T} 1, \mathrm{~T} 2, \mathrm{~T} 5, \mathrm{~T} 6, \mathrm{~T} 8, \mathrm{~T} 9, \mathrm{~T} 12, \mathrm{~T} 15)$ & 8 & 47 \\
Gender has & No difference (T3,T4,T7,T11,T13,T16,T17) & 7 & 41 \\
no effect & Tendency in learning a language (T10) & 1 & 5 \\
& & & \\
\hline \multirow{2}{*}{ Has effect } & Girls are more effective (T14) & & \\
\hline
\end{tabular}

When table 3 is analysed, with \%47 the most effective factor is "not depending on the gender, personality is more important", \%41 "no affect", \%5 "effect on the language", \%5 "girls can better learn" can be seen. 
The citations taken one-to-one from the teachers' comments are :

"I'm opposite to the gender difference son I think there is no difference. "(T2)

"I think gender has no effect on learning a language. Within their wishes, they can learn in living. “(T12)

“The girls has a little more effective learning on language.”(T14)

Tablo 4. Teachers' opinions about the hardest method in understanding the lecture

\begin{tabular}{llll}
\hline $\begin{array}{l}\text { Theme } \\
\text { (Category) }\end{array}$ & Codes & $\mathbf{n}$ & \% \\
\hline & Speaking ( T1,T2,T3,T4,T5,T6,T7,T8,T9,T10,T11,T12 & 16 & 95 \\
& T13,T14,T15,T17) & & \\
& Listening (T1,T6,T8,T13) & 4 & 23 \\
The & Writing (T3,T5,T6,T7) & 4 & 23 \\
hardest & Word knowledge (T4,T5,T6) & 3 & 17 \\
method & Grammar (T14) & 1 & 5 \\
& Studying ( T2) & 1 & 5
\end{tabular}

When Table 4 is analysed, with \%95 the hardest method is considered as "speaking".After, \%23 "listening and writing" . \%17 "lack of word knwledge" is coming. Only one teacher has the opinion that says "these all have no effect on learning" and considers only "studying" is needed.

The citations taken one-to-one from the teachers' comments are :

"This question is not useful. All the choices are corelated in each other. No one of these can happen without other. The most important is studying." (T2)

"Word knowledge, writing, speaking.These are insufficient. The reason can be not using in the classroom or not being effective in the classroom.” (T5)

"Speaking I think. They can not act in courage in speaking. "(T16)

Tablo 5. Teachers' opinions about the problems confronted in the learning period

\begin{tabular}{llll}
\hline $\begin{array}{l}\text { Theme } \\
\text { (Category) }\end{array}$ & Codes & $\mathbf{n}$ & $\%$ \\
\hline & Not sharing suitable study time (T2,T3) & 2 & 11 \\
& The idea of making wrong (T1,T15) & 2 & 11 \\
& Not speaking (T4,T11,T13,T15,T16) & 5 & 29 \\
The problems & Not writing sufficiently (T15,T16) & 2 & 11 \\
confronted in & Give particular importance on native language (T7,T10) & 2 & 11 \\
learning & Lack of practice (T8,T12,T17) & 3 & 17 \\
& Lack of word knowledge (T9,T16) & 2 & 11
\end{tabular}


When Table 5 is analysed, "not speaking" has the \%29 with the first place, \%17 "no practises" has the second. Within \%11 "not sharing suitable study time and give particular importance on native language" are considered as the forthcoming.

The citations taken one-to-one from the teachers' comments are :

“They don't share time. They don't use it in their lives.For example, we taught them the basic meals or foods, when they go to a market or restaurant they don't ask about them, they don't bother themselves about learning some new things". (T3)

"Within thinking in Turkish, their native language, you can not learn a foreign one. This is the main problem. Besides, if you learn the grammatical parts of the language you have to use the practical parts that you have learned from internet, TV or some other source. “(T7)

"They are not effectively using the information that they have learned in the lectures.."(T11)

Tablo 6. Teachers' opinions about the affect of the lifetime and the culture of a foreign language

\begin{tabular}{llll}
\hline Theme/Category & Codes & $\mathbf{n}$ & \% \\
\hline & Makes easier the learning (T4,T13,T14,T16,T17) & 5 & 29 \\
$\begin{array}{l}\text { Culture } \\
\text { is } \\
\text { effective }\end{array}$ & Is important, positive effects (T3,T6,T7,T9,T10,T12) & 6 & 35 \\
& Enriches the meaning (T3,T9,T15) & 3 & 17 \\
& & & \\
\hline $\begin{array}{l}\text { Culture is } \\
\text { ineffective }\end{array}$ & Culture has no effect (T1,T2,T5,T11) & & \\
\hline
\end{tabular}

When Table 6 is analysed, \%35 of the participants have the idea "Culture is important, has positive affect", \%29 thought "makes easier the learning” , \%17 "enriches the meaning". \%23 part defines culture as "ineffective".

The citations taken one-to-one from the teachers' comments are :

"If you are learning a language of course culture is going to have a vital part in it. With the idioms and proverbs, the cognition gets better. "(T3)

"No effect is possible. While learning the language,you don't have to gather the culture or to apply it. Actually, while you are learning, your culture about it gets increased. “(T5)

"Culture isvery important about understanding the issue. While studying it enriches the meaning. Witout using the culture, you can not learn the language. "(T8) 
Tablo 7. Teachers' opinions about the affect of the activities that can be done outside the classroom about learning a language ?

\begin{tabular}{llll}
\hline $\begin{array}{l}\text { Theme } \\
\text { (Category) }\end{array}$ & Codes & $\mathbf{n}$ & \% \\
\hline & Visual ( Cinema ) (T3,T6,T7,T9,T15) & 5 & 29 \\
& Reading, Listening exercises ( T1,T7,T8,T11) & 4 & 23 \\
& Speaking with foreginers (T5,T6,T12,T13,T14) & 5 & 29 \\
& Debates (T1,T7,T16,T17) & 4 & 23 \\
Outdoor & Travel (T5,T10,T12,T14) & 4 & 23 \\
activities & Using social media ( T1,T3) & 2 & 11 \\
& Participate in seminars (T17) & 1 & 5
\end{tabular}

When Table 7 is analysed, it can be seen as \%29 "Visual" and "Speaking with foreigners"take the first place,after \%23 "debate", "travel” and " reading-listening " studies are following. \%11 said "Social media using" can be used as an activity.

The citations taken one-to-one from the teachers' comments are :

“Cinema activities, debates, whatsupp groups can use english very well.” (T3)

"Considered within the issue, reading, writing and translation activities are effective. Making critics about a watched film or making debates are useful. "(T7)

"Traveling in the country that language is used and also communication can be made with the citizens."(T12)

“Joining abroad projects,entering youth camps, finding penpals are suitable. “(T14)

\section{Conclusion and recommandations}

The results gathered from the research on foreign language learning and teaching within the theme "Why we can not teach a foreign language?" are stated : 1-For teaching a foreign language, the used methods auido-visual and establishing dialogue are preferred by the students, the grammatical studies are not. 2- The most inefficient factors on learning are considered as the studies made by the teacher are mostly in native language and not transfering the studies to the daily life. 3- The gender difference has no effect on learning, the personality has. 4- The most hardest method to understand the language can be considered as speaking. 5- During the study period, the hardest problem is depending on speaking and avoiding it. 6- Culture has an important part in language learning. 7-It can be inferred that outside of the classroom, the most effective learning can be made with the foreign people. As to the results of the research, the administrations that have the responsibility on learning and teaching foreign language - also these can be foundations or enterprises - can be considered as different aspects of the teachers. These aspects can be defined as new politics and depending on these new politics, all the process on teaching based on mechanical exercises and with the aim of gathering mechanical students, the students are not preferring these studies, and they want audio-visual or speaking activities more. ( Demirel, 1993 ). When the contents of the books are examined, almost all of them have fill in the blanks, matching, finding the false or true and so on exercies types and also using 15 
units they finish the semester, and the student stays in an endless loop within only learning some new words and passes the learning period. But, the students expectations about this stiuaiton are to improve their speaking abilities and can define what he or she has heard easily in daily life situations. In cafeterias, classrooms, libraries and such places like these, almost all the students have the same thoughts on learning a language is based on thses simple questions " how much you know speaking " or "I understand but I can't talk" .An interesting result from the research is, the culture coming from the language has an important role within the communication between the student and the teacher and also in the learning period. For example, while you are learning English, there is going to be real important difference betwwen learning it from an English or American teacher or from a Turkish one. Some of these difference can be defined as coming from the accent maybe, but the important part is how the student is going to be effected by them . At this point, culture is getting an important part (Byram, 1997). If you teach a language with using a teacher from its native land, the students have more interest on that kind of study. This can be explained with, speakings, body gestures, eating or drinking something and so on examples are mostly interrelated with the culture directly and making easier the learning phase. In spite of this, the students' attempts on only using the books and with using his or her abilities on translation have insufficient affect on learning period and we can define them useless. As a general conclusion, the teaching and the learning methods need to be changed comprehensively. These changes can be defined like : gathering a new aspect depending on audio-visual and speaking abilities, being more intimate with the culture and this also provides employment of foreign teachers, not study in classical classroom ambients, doing different kind of outdoor activities and the most important of them all is to be considered as the best feature of a humanbeing antropologically "talking" can be applied more easily in daily life.

\section{REFERENCES}

- AYDIN, Ö. ( 2001 ). “İkinci Dil Ediniminde Evrensel Dilbilgisine Erişim Türkçede Erişim Varsayımlannın Sınanması “, Hacettepe Üniversitesi, Edebiyat Fakültesi, İngiliz Dilbilimi Bölümü Dilbilim ve Uygulamaları Dergisi, Sayı: 2

- BYRAM, M. ( 1997 ).” Teaching and Assessing Intercultural Communicative Competence, Clevedon: Multilingual Matters"

- CHOMSKY, N. ( 2008, June ) "Interview with Noam Chomsky, 'Human nature and the origins of language.", Radical Anthropology magazine

- DEMİREL, Ö. ( 1993 ). "Yabancı Dil Öğretimi”. Usem Yay. 6, 3. baskı, Ankara

- EKMEKÇİ, Ö. ( 1983, Temmuz/Ağustos ). Türk Dili, Dil Öğretim Özel Sayısı, TDK Yay., (ss. 379-380)

- JOHNSON, K. ( 1982 ). "Communicative Syllabus Design and Methodology." Oxford, Pergomon Institute of English.

- KABADAYI, A. ( 2003 ). "Öğrenci-Merkezli Yabancı Dil Öğretim Modeli Tercih Ölçeği (YÖMTÖ) “. Dokuz Eylül Üniversitesi Sosyal Bilimler Enstitüsü Dergisi Cilt 5, Sayı:1.

- YILDIRIM, A. ve ŞİMŞEK, H. (2008). Sosyal bilimlerde nitel araştırma yöntemleri (6. Baskı).Ankara: Seçkin Yayınları 